Supplement of Atmos. Chem. Phys., 15, 9983-9996, 2015

http://www.atmos-chem-phys.net/15/9983/2015/

doi:10.5194/acp-15-9983-2015-supplement

(C) Author(s) 2015. CC Attribution 3.0 License.

(c) (i)

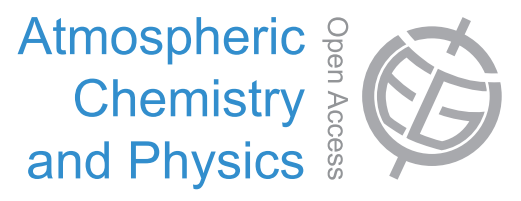

Supplement of

\title{
Diesel-related hydrocarbons can dominate gas phase reactive carbon in megacities
}

R. E. Dunmore et al.

Correspondence to: J. Hamilton (jacqui.hamilton@york.ac.uk)

The copyright of individual parts of the supplement might differ from the CC-BY 3.0 licence. 


\section{Supplementary Information}

\subsection{Speciated Emission Inventory Calculations}

The speciated emissions inventory supplied in a report from Passant (2002) provides data on a large range of individual NMHCs and their specific emission sources. From this comprehensive speciation

5 profile, it is possible to apply the most recent UK National Atmospheric Emissions Inventory (NAEI) from 2012 and calculate scaling factors that can applied to each source category (The UK NAEI data is available at http://naei.defra.gov.uk/data/data-selector, and was accessed on 30/01/2014). The speciated proportion profiles of the individual NMHCs emitted from given sources should not change significantly, however the total emission from a source will as a result of changes in activity levels and the impact of regulations/abatement. The US has no equivalent NAEI speciated emission inventory. The SPECIATE database (U.S. Environmental Protection Agency (EPA)) provides detailed species profiles for a larger range of emission sources (The US EPA SPECIATE data is available at http://cfpub.epa.gov/si/speciate/, and was accessed on 20/02/2014). In order to compare directly to the UK NAEI from Passant, the SPECIATE emission profiles are used to calculate scaling factors as above. All VOC sources have been included in the inventory calculation with the exception of the Forests source category, due to the lack of chemical speciation (given as isoprene+BVOC). There is a small anthropogenic emission source of terpenoids in the inventory from fuel sources and wood product manufacture categories.

\subsection{Differences between London and Previous US studies}

\subsubsection{Weekday versus weekend differences in diesel emissons}

Previous measurements of VOCs in Bakersfield showed a lower toluene/benzene ratio $(\mathrm{t} / \mathrm{b})$ at the weekend $(\mathrm{t} / \mathrm{b}=1.7)$ compared to weekdays $(\mathrm{t} / \mathrm{b}=2.4)$ (Bahreini et al. 2012). This was used as an indicator of reduced photochemistry at the weekend as a result of changes in diesel emissions due to reductions in heavy-duty vehicles. Using this same approach, the winter campaign ratio has been calculated for weekends $(t / b=2.6)$ and weekdays $(t / b=2.2)$, the opposite of the Bakersfield study, with a higher $\mathrm{t} / \mathrm{b}$ ratio at the weekend, although it should be noted that the correlation between the two species is poorer during the weekdays $\left(R^{2}=0.73\right.$, c.f. weekend $\left.R^{2}=0.96\right)$. Also, no discernable differences were found between the behavior of gasoline (2,2,4-trimethyl pentane and toluene) and diesel tracers ( $n$-dodecane, $\mathrm{C}_{13}$ aliphatics) as shown in SI Figure 11, with average diurnal profiles at the weekends shown in blue and weekdays in red. In general there are lower concentrations during the evening rush hour (16:00-19:00) of all VOCs and $\mathrm{NO}_{x}$ at the weekend, with an increase later in the evening (19:00-00:00), reflecting the increase in nighttime social activities during the weekends. However, the highest mixing ratios of most VOCs were observed on Sat 14/01/2012, as a result of low wind speeds and a low boundary layer depth. The traffic make up in London is different to US cities, with a high degree of diesel powered buses and cars. Thus the influence of reduced heavy-duty truck traffic is not observed in the ratio of diesel to gasoline VOCs.

\subsubsection{Comparison of London and Los Angeles}

SI Table 1 shows the differences between London and Los Angeles in terms of population density, green space and diesel fuel use to highlight the very different urban geography and traffic make up in the two cities. A smaller sub set of data is also included for North Kensington, where this study was carried out and Bakersfield, CA, the site of the CALNEX project.

This comparison is particularly important when considering the sources of BVOCs. In California, where many of the previous studies have taken place, the cities are surrounded by high BVOC emitting regions i.e. Blodgett Forest, Angeles National Park, Sequoia National Park and Los Padres National Park. Los Angeles itself only has around 6.7\% public greenery. In contrast, London has an estimated $38 \%$ public green space and is the greenest city of its size in the World. The emission 
maps shown in SI Figure 2 show that current emission models do not predict a significant downwind source of BVOC to London. Therefore in summer in London, the majority of BVOCs measured are likely to be from relatively local sources.

\subsection{Calibrations and Uncertainties}

Gas phase calibrations were performed at regular intervals on both instruments using a standard (NPL30, National Physical Laboratory, Teddington, UK) containing 30 ozone precursor species $\left(\mathrm{C}_{2^{-}}\right.$ $\mathrm{C}_{8}$ ) at 3-5 ppb levels. For the higher carbon number hydrocarbons measured on the $\mathrm{GC} \times \mathrm{GC}$, a separate NPL standard was used which contained 24 species from $\mathrm{C}_{5}-\mathrm{C}_{11}$ (including a range of aromatics). However many of the higher hydrocarbon measurements from the GC $\times$ GC-FID were ultimately based on calibrations from liquid standards introduced by splitless injection. Instrument zeros, including testing of sample lines and water removal stages, were made using high purity $\mathrm{N}_{2}$, with further purification using an Aeronex Gatekeeper catalyst.

For those compounds not included in gas standard mixtures, a response factor (RF) was calculated from liquid injections, to allow compound concentrations to be quantified (Equation 11). This was determined as the response of a compound (i) with respect to a reference compound (ref), where $R_{r e f, s t}$ and $R_{i, s t}$ are the responses of the reference and i compounds in the standard (or in this case from liquid mixtures, st) respectively, and $C_{r e f, s t}$ and $C_{i, s t}$ are the corresponding concentrations (de Blas et al., 2011). The response factor can then be used in a second equation to quantify the concentrations of the compounds in air samples. This is shown in Equation 2, where $X_{r e f}$ and $X_{i}$ are the concentrations of the reference and i compounds in air samples, and $P A_{r e f}$ and $P A_{i}$ are the peak areas of the reference and i compounds respectively. For the grouped compounds (see Figure 2 of the main paper and SI Table 3), the $n$-alkane response has been used for quantification as FID response is assumed to be linear with carbon number (Slemr et al., 2004).

$R F_{i \cdot r e f}=\frac{R_{r e f, s t} \times C_{i, s t}}{R_{i, s t} \times C_{r e f, s t}}$

$\left[X_{i}\right]=\frac{\left(\frac{P A_{i}}{P A_{r e f}}\right) \times\left[X_{r e f}\right]}{R F_{i \cdot r e f}}$

Measurement uncertainties are described in Hopkins et al. (2003) and Lidster et al.(2011) however they are broadly dominated by the gravimetric uncertainty associated with gas standard preparation, typically $5 \%$. Run to run reproducibility was better than $1 \%$ for light $\mathrm{C}_{2}-\mathrm{C}_{7}$ hydrocarbons (when $>1$ $\mathrm{ppb})$ and better than $5 \%$ for higher hydrocarbons. The expanded uncertainty $(\mathrm{k}=2)$ for the carbon class measurements reported in this article are estimated at $6 \%$ for $\mathrm{C}_{2}-\mathrm{C}_{7}$ and $5-11 \%$ for $\mathrm{C}_{8}-\mathrm{C}_{13}$ (depending on the specific compound).

\subsection{Benzene Correlations}

There were a number of species that were observed on both GC instruments ( $n$-hexane, 2/3-methyl pentane, $n$-heptane, $n$-octane, 2,2,4-trimethyl pentane, isoprene, benzene, toluene, ethyl benzene, $\mathrm{m} / \mathrm{p}$-xylene, $o$-xylene and acetone). The agreement between both instruments for these species is good as typified by the observations of benzene shown in SI Figure 4.

\subsection{GC $\times$ GC-FID full identification and concentrations}

Individually identified compounds are shown in SI Figure 5 (where the numbers represent the peak identity in SI Table 2), a typical GC $\times$ GC-FID plot, where the retention times from column 1 (separation based on volatility) and column 2 (separation based on polarity) are the $\mathrm{x}$ and $\mathrm{y}$ axis respectively, 
and compound intensity is the coloured contour. Two simplified bands of compounds can be seen; an aromatic band that is well separated from the aliphatic band, however, these are just general features and some oxygenated and other hetero species are present: both within and outside these lines. Figure $5 \mathrm{~b}$ and $5 \mathrm{k}$ are expanded sections of Figure $5 \mathrm{a}$ to improve visualisation.

\subsection{Impact of local meteorology in winter}

Ethane shows a different behaviour characteristic of a persistent fugiative release, in this case from the natural gas network (de Gouw et al. 2005, Borbon et al. 2001), and is also impacted by changing boundary layer height. In the original winter diurnal profile of ethane (which includes all data points, seen in SI Figure 6, blue profile), a pattern is seen which appears to show a large increase in the early morning hours. This is likely due to two stagnant, high pressure periods experienced at the start and end of the campaign where data profiles were driven by meteorological conditions (10/01/201218/01/2012 and 03/02/2012-08/02/2012). The dispersion of VOCs would be low given decreased wind speeds, and as such the ethane concentration would appear to rise.

100 In order to see the most accurate profile of ethane, the data points corresponding to the two stagnant periods were removed and a new diurnal profile constructed (shown in SI Figure 6 red profile). This shows the expected diurnal profile. The 'dip' seen in both profiles of ethane at approximately 12 noon correlates to a rise in the boundary layer. A boundary layer decrease in the afternoon is also seen to have an effect on the profiles of ethane with a small rise at approximately 15:00. There is no difference seen in the two profiles of the other individual VOCs and grouped species, except for a larger range in the unconstrained profiles, likely due to the higher concentrations seen during the two stagnant, high pressure periods and their shorter lifetime in the atmosphere compared to ethane.

\subsection{Calculation of primary hydrocarbon $\mathrm{OH}$ reactivity}

The following equation was used to calculate the primary hydrocarbon $\mathrm{OH}$ reactivity, using observed

meteorological data ( $\mathrm{T}$ and $\mathrm{p}$ ). Due to a lack of information on rate constant temperature dependence for most species, the $298 \mathrm{~K} k_{O H}$ rate constants were used from Atkinson and Arey (2003) for all individually identified species.

$\mathrm{s}^{-1}=\left([\mathrm{VOC}](\mathrm{ppb}) \times 10^{-9} \times[\mathrm{M}]\right) \times k_{O H}(298 \mathrm{~K})$

Where

$[\mathrm{M}]=\left(\frac{\text { Pressure }(\mathrm{mbar}) \times 10^{-4}}{(8 \cdot 314 \times(273 \cdot 15+\text { temperature }))}\right) \times 6 \cdot 022 E+23$

For each aliphatic group, the appropriate $\mathrm{C}$ number $n$-alkane $k_{\mathrm{OH}}$ rate constant was used to calculate the primary $\mathrm{OH}$ reactivity. Each group is likely to contain branched alkanes, cycloalkanes and alkenes in addition to the $n$-alkane. The measured rate constants of branched alkanes with $\mathrm{OH}$ are usually similar or slower than the linear alkane, depending on the location and degree of branching. There are very few measurements of $\mathrm{OH}$ rate constants for cycloalkanes, but generally they react faster than the equivalent linear alkane. Alkenes react around an order of magnitude faster with $\mathrm{OH}$ than alkanes, and the rate increases further with increasing degrees of unsaturation.

Due to a lack of isomer speciation and kinetic data above $\mathrm{C}_{9}$, the $n$-alkane rate constant was used to allow direct comparison between the $\mathrm{C}_{\mathrm{n}}$ groups. This is likely to represent a small underestimate of the group as a whole as we assume no alkene contribution to the reactivity of the group. We calculated $\mathrm{OH}$ rate constants $(298 \mathrm{~K})$ for $354 \mathrm{C}_{12}$ alkane isomers using the $\mathrm{H}$ atom abstraction structure activity relationship defined in Ziemann and Atkinson (2012). The average rate constant was found to be $1.15 \times 10^{-11} \mathrm{~cm}^{3}$ molecule ${ }^{-1} \mathrm{~s}^{-1}$ which, when compared to the measured rate 
constant for $n$-dodecane $\left(1.32( \pm 0.26) \times 10^{-11} \mathrm{~cm}^{3}\right.$ molecule $\left.{ }^{-1} \mathrm{~s}^{-1}\right)$, is within the error limits for this measurement (Atkinson, 2003). A selection of the calculated rate constants are shown in SI Table 4, along with some alkenes to highlight the range of reactivities of the $\mathrm{C}_{12}$ species.

For the $\mathrm{C}_{10}$ terpenoid group the use of $\alpha$-pinene rate constant $\left(5.23 \times 10^{-11} \mathrm{~cm}^{3}\right.$ molecule $\left.{ }^{-1} \mathrm{~s}^{-1}\right)$ produces a conservative underestimate of the $\mathrm{OH}$ reactivity for this group, as it is one of the slowest reacting species, c.f. limonene $\left(1.64 \times 10^{-10} \mathrm{~cm}^{3}\right.$ molecule $\left.\mathrm{e}^{-1} \mathrm{~s}^{-1}\right)$ (Atkinson and Arey, 2003). If a rate constant half way between $\alpha$-pinene and limonene $\left(1.08 \times 10^{-10} \mathrm{~cm}^{3}\right.$ molecule $\left.{ }^{-1} \mathrm{~s}^{-1}\right)$ was used, this would increase the contribution of the $\mathrm{C}_{10}$ terpenoid group to primary $\mathrm{OH}$ reactivity from 0.009 $\mathrm{s}^{-1}$ to $0.019 \mathrm{~s}^{-1}$ and $0.041 \mathrm{~s}^{-1}$ to $0.086 \mathrm{~s}^{-1}$ in winter and summer respectively.

\subsection{Effect of fuel composition on the calculation of emission sources}

The differences in fuel composition of gasoline and diesel from the UK and US may have an effect on the calculations presented in this study. This could be particularly important for the middle range carbon number species, as the US has strict guidelines on the addition of so called "heavy hydrocarbons" (i.e. $\mathrm{C}_{9}-\mathrm{C}_{11}$ aromatic species) to gasoline. By comparison, the UK has more stringent controls of the composition of diesel fuel. This has been addressed by re-calculating the contributions of total diesel emissions to mixing ratio, mass, $\mathrm{OH}$ reactivity and OFP with and without the specified $\mathrm{C}_{9}$ aromatic content as presented in Gentner et al. (2013). The results of this analysis is given in SI Table 6, which shows that excepting winter OFP $(2.1 \%)$, is equal to or less than a $1 \%$ difference.

\subsection{Fuel usage changes}

Department of Energy and Climate Change statistics (www.gov.uk/government/statistical-data-sets/roadtransport-energy-consumption-at-regional-and-local-authority-level , and was accessed on 30/04/2014) give a regional breakdown of the total diesel and fuel consumption from 2005 to 2011 and are shown below for the UK in SI Table 7 and SI Figure 7 


\section{References}

Aschmann, S. and Atkinson, R.: Rate constants for the gas-phase reactions of OH radicals with E-7-tetradecene, 2-methyl-1-tridecene and the $\mathrm{C}_{7}-\mathrm{C}_{14}$ 1-alkenes at $295 \pm 1 \mathrm{~K}$, Physical Chemistry Chemical Physics, 10, 4159-4164, doi 10.1039/B803527J 2008.

Atkinson, R.: Kinetics of the gas-phase reactions of $\mathrm{OH}$ radicals with alkanes and cycloalkanes, Atmospheric Chemistry and Physics, 3, 2233-2307, doi 10.5194/acp-3-2233-2003. 2003.

Atkinson, R. and Arey, J.: Atmospheric degradation of volatile organic compounds, Chemical Reviews, 103, 4605-4638, doi 10.1021/cr0206420 2003.

Bahreini, R., Middlebrook, A. M., de Gouw, J. A., Warneke, C., Trainer, M., Brock, C. A., Stark, H., Brown, S. S., Dube, W. P., Gilman, J. B., Hall, K., Holloway, J. S., Kuster, W. C., Perring, A. E., Prevot, A. S. H., Schwarz, J. P., Spackman, J. R., Szidat, S., Wagner, N. L., Weber, R. J., Zotter, P., and Parrish, D. D.: Gasoline emissions dominate over diesel in formation of secondary organic aerosol mass, Geophysical Research Letters, 39, doi:10.1029/2011GL050718, 2012.

Borbon, A., Fontaine, H., Veillerot, M., Locoge, N., Galloo, J., and Guillermo, R.: An investigation into the traffic-related fraction of isoprene at an urban location, Atmospheric Environment, 35, 3749-3760, doi $10.1016 / \mathrm{S} 1352-2310(01) 00170-4.2001$.

de Blas, M., Navazo, M., Alonso, L., Durana, N., and Iza, J.: Automatic on-line monitoring of atmospheric volatile organic compounds: Gas chromatography-mass spectrometry and gas chromatography-flame ionization detection as complementary systems, Science of the Total Environment, 409, 5459-5469, 2011.

de Gouw, J., Middlebrook, A., Warneke, C., Goldan, P., Kuster, W., Roberts, J., Fehsenfeld, F., Worsnop, D., Canagaratna, M., Pszenny, A., Keene, W., Marchewka, M., Bertman, S., and Bates, T.: Budget of organic carbon in a polluted atmosphere: Results from the New England Air Quality Study in 2002, Journal of Geophysical Research-Atmospheres, 110, doi:10.1029/2004JD005623. 2005.

Gentner, D., Isaacman, G., Worton, D., Chan, A., Dallmann, T., Davis, L., Liu, S., Day, D., Russell, L., Wilson, K., Weber, R., Guha, A., Harley, R., and Goldstein, A.: Elucidating secondary organic aerosol from diesel and gasoline vehicles through detailed characterization of organic carbon emissions, Proceedings of the National Academy of Sciences of the United States of America, 109, 18 318-23, doi 10.1073/pnas.1212272109 2012.

Gentner, D., Worton, D., Isaacman, G., Davis, L., Dallmann, T., Wood, E., Herndon, S., Goldstein, A., and Harley, R.: Chemical composition of gas-phase organic carbon emissions from motor vehicles and implications for ozone production, Environmental Science \& Technology, 47, 11837-11848, doi:10.1021/es401470e, 2013.

Hopkins, J., Lewis, A., and Read, K.: A two-column method for long-term monitoring of non-methane hydrocarbons (NMHCs) and oxygenated volatile organic compounds (OVOCs), Journal of Environmental Monitoring, 5, 8-13, doi $10.1039 / \mathrm{b} 202798 \mathrm{~d} 2003$.

Kwok, E. and Atkinson, R.: Estimation of hydroxyl radical reaction-rate constants for gas-phase organiccompounds using a struture-reactivity relathionship - an update, Atmospheric Environment, 29, 1685-1695, doi: $10.1016 / 1352-2310(95) 00069-B, 1995$.

Lidster, R., Hamilton, J., and Lewis, A.: The application of two total transfer valve modulators for comprehensive two-dimensional gas chromatography of volatile organic compounds, Journal of Separation Science, 34 , 812-821, doi $10.1002 /$ jssc.201000710 2011.

Passant, N.: Speciation of UK emissions of non-methane volatile organic compounds, Tech. rep., AEA Technology Report ENV-05452002, Culham, Abingdon, United Kingdom, 2002.

Slemr, J., Slemr, F., D'Souza, H., and Partridge, R.: Study of the relative response factors of various gas chromatograph-flame ionisation detector systems for measurement of $\mathrm{C}_{2}-\mathrm{C}_{9}$ hydrocarbons in air, Journal of Chromatography A, 1061, 75 - 84, doi 10.1016/j.chroma.2004.10.037. 2004.

Stewart, H., Hewitt, C., Bunce, R., Steinbrecher, R., Smiatek, G., and Schoenemeyer, T.: A highly spatially and temporally resolved inventory for biogenic isoprene and monoterpene emissions: Model description and application to Great Britain, Journal of Geophysical Research: Atmospheres, 108, doi 10.1029/2002JD002694. 2003.

Ziemann, P. and Atkinson, R.: Kinetics, products, and mechanisms of secondary organic aerosol formation, Chemical Society Reviews, 41, 6582-6605, doi:10.1039/C2CS35122F 2012. 

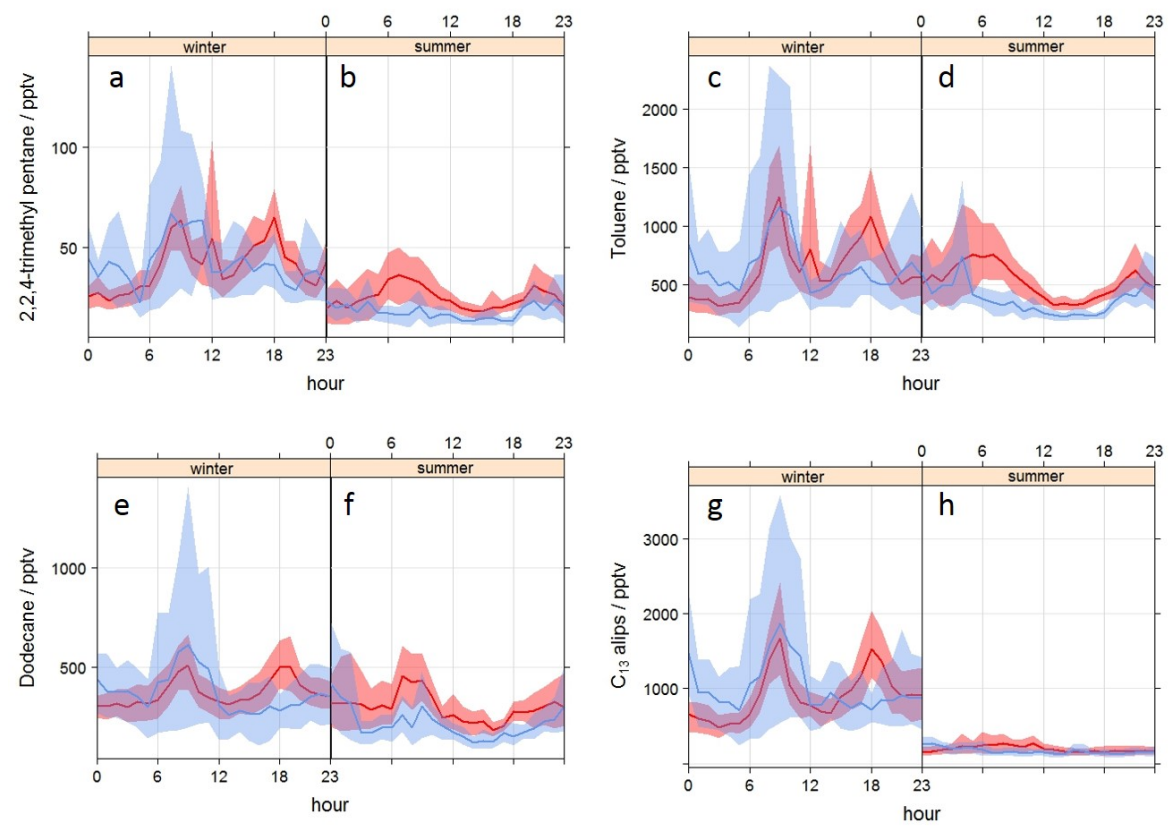

Figure 1. Diurnal profiles of typically traffic source related compounds showing weekday (red) and weekend (blue) profiles. Petrol compounds are toluene and 2,2,4-trimethyl pentane and diesel compounds are $n$-dodecane and $\mathrm{C}_{13}$ aliphatics

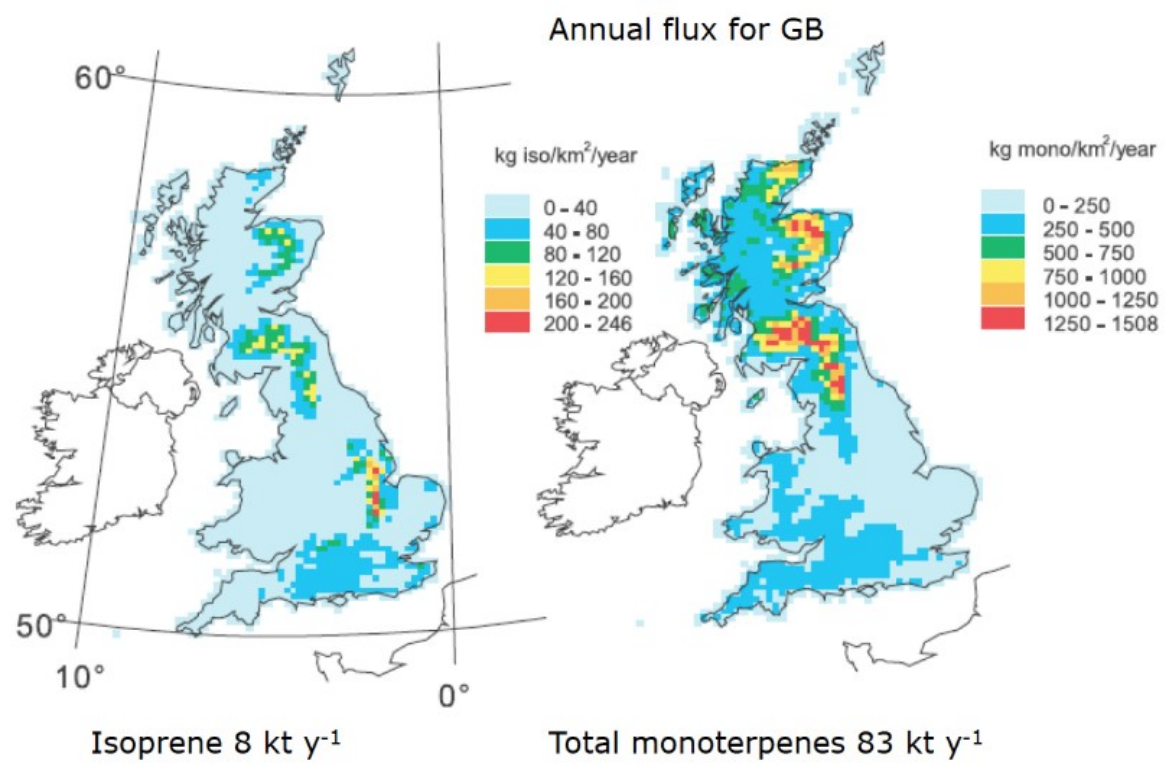

c.f. anthrop VOC flux $1800 \mathrm{kt} \mathrm{y^{-1 }}$

Figure 2. Isoprene and monoterpene annual flux for Great Britain in 1998. (Stewart et al. 2003) 


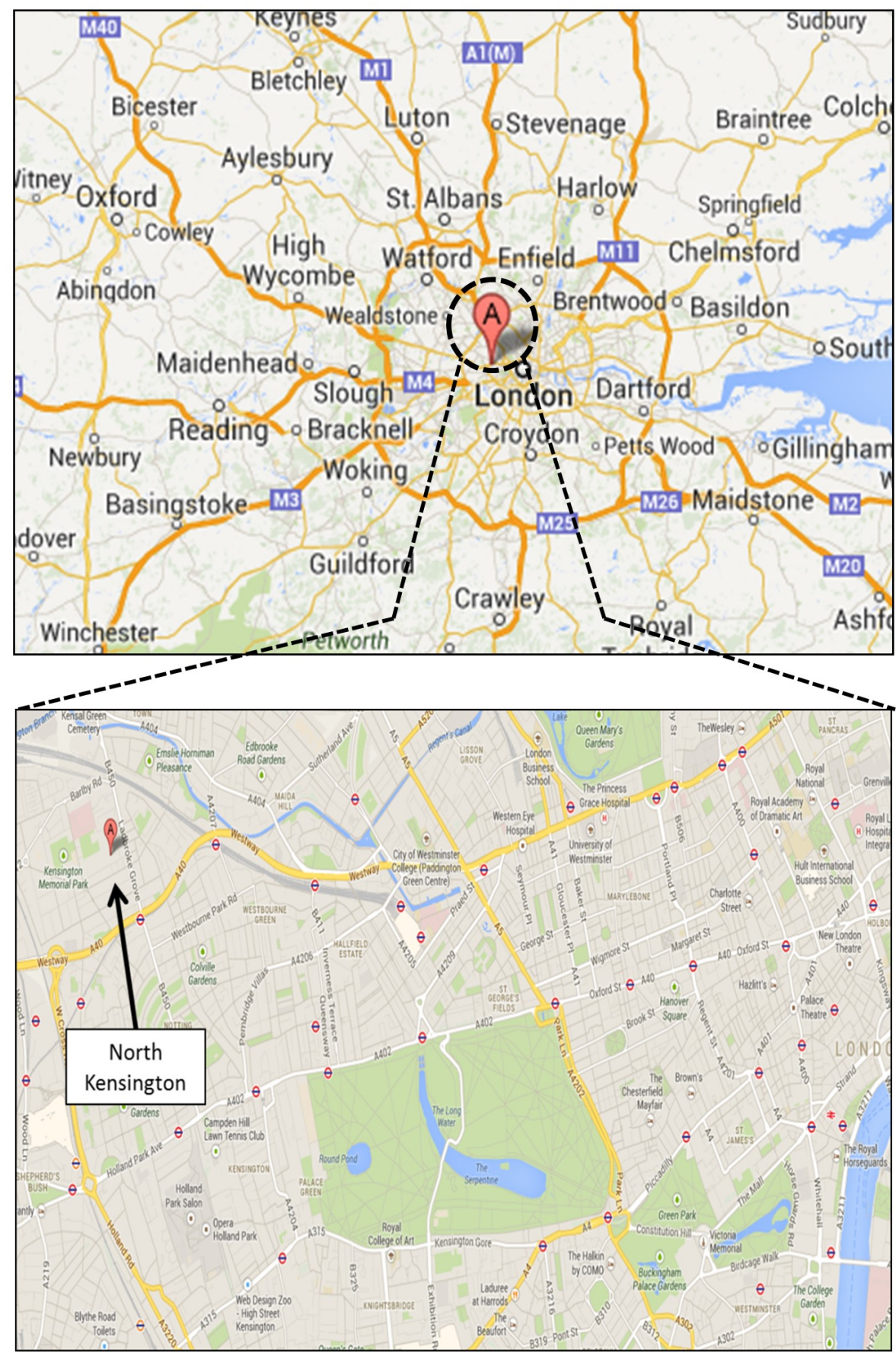

Figure 3. Location of the North Kensington site 


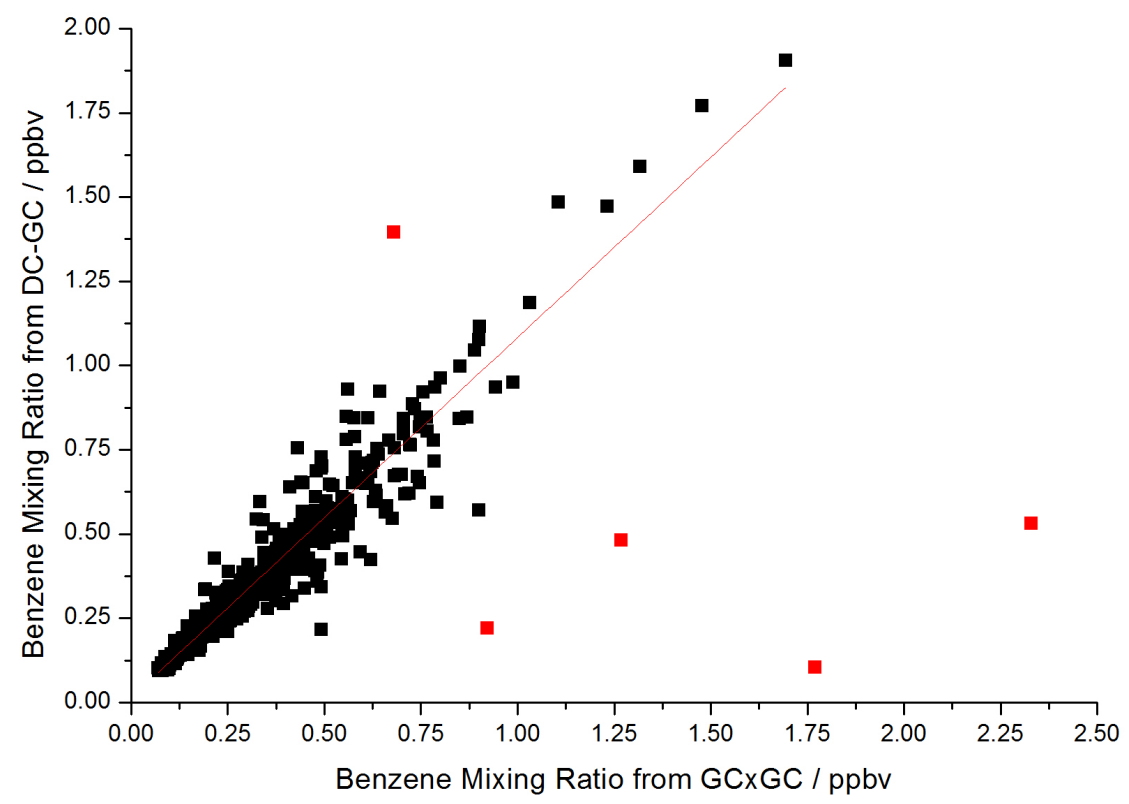

Figure 4. Benzene correlation for the GC $\times$ GC-FID (x-axis) and the DC-GC-FID (y-axis) instruments, $R^{2} 0.92$, slope $1.070 \pm 0.013$. Points shown in red have been removed from the correlation as outliers

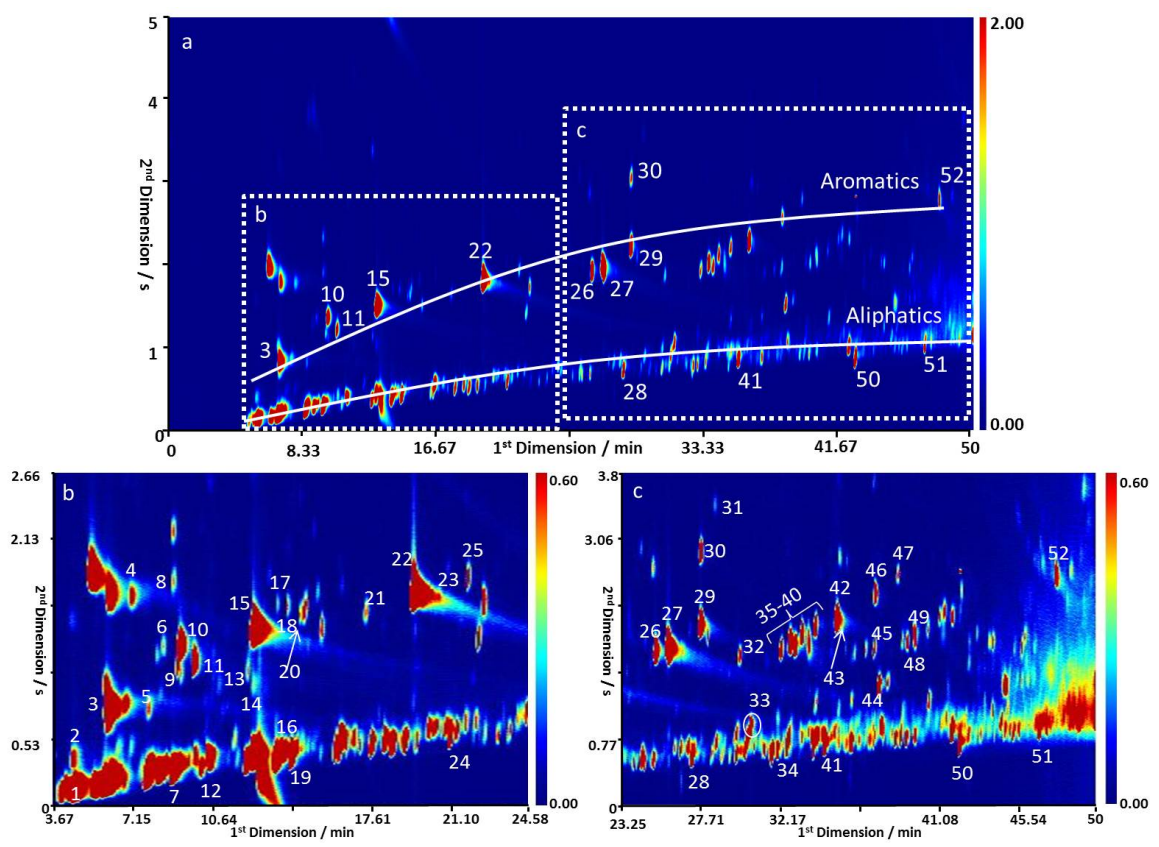

Figure 5. A typical GC $\times$ GC-FID plot from 2012-02-07 at 08:32, showing two separate bands of compounds, aromatic and aliphatics. Box b and $\mathrm{c}$ show zoomed in sections of the original plot. Labelled peaks for sections $\mathrm{a}, \mathrm{b}$ and $\mathrm{c}$ are given in Table 2 

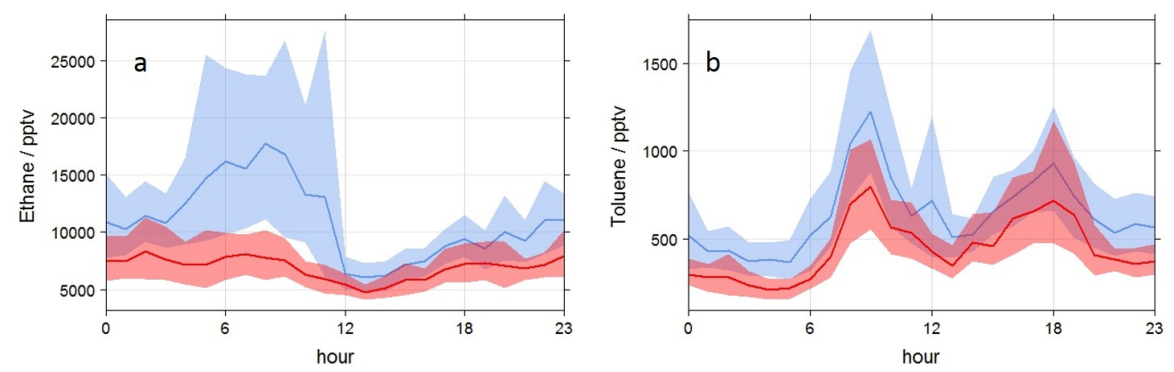

Figure 6. Winter profiles of ethane (left) and toluene (right), showing the effect of changing meteorology. a, ethane ( $n=660$ and 353, blue and red, respectively) and b, toluene ( $n=660$ and 353)

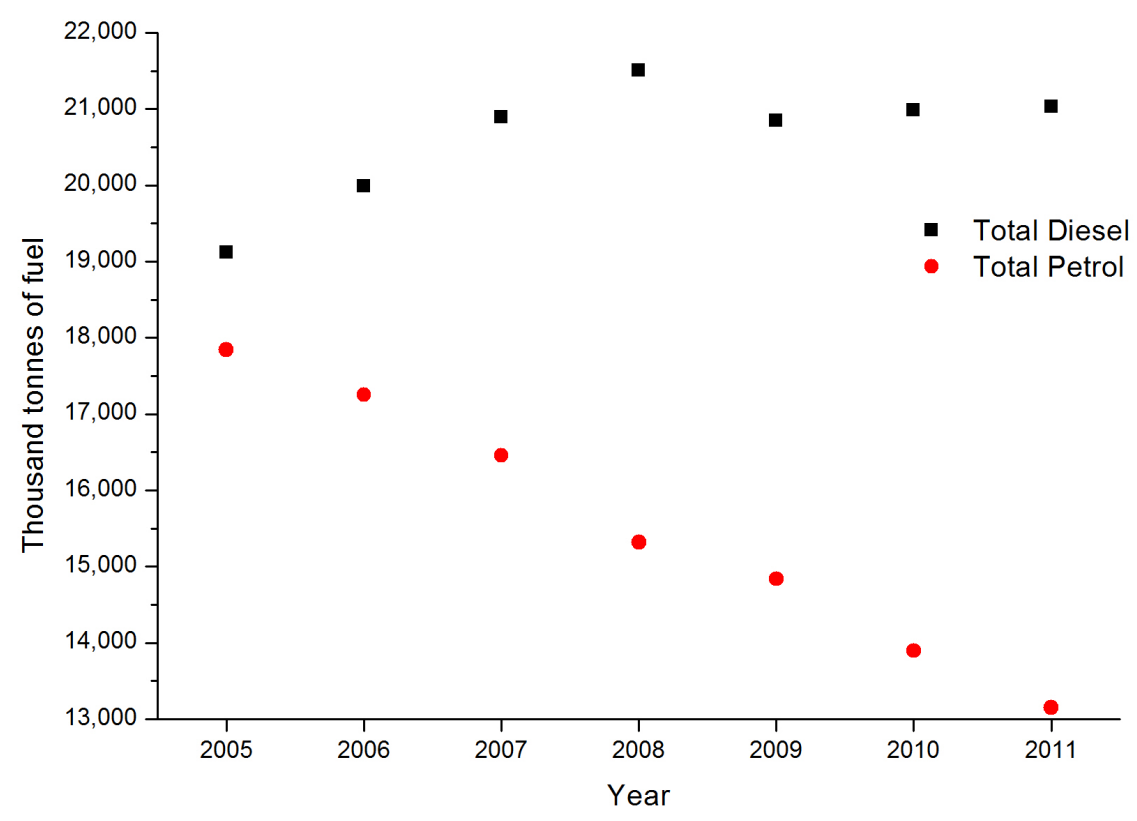

Figure 7. Change in fuel use from 2005 to 2011 


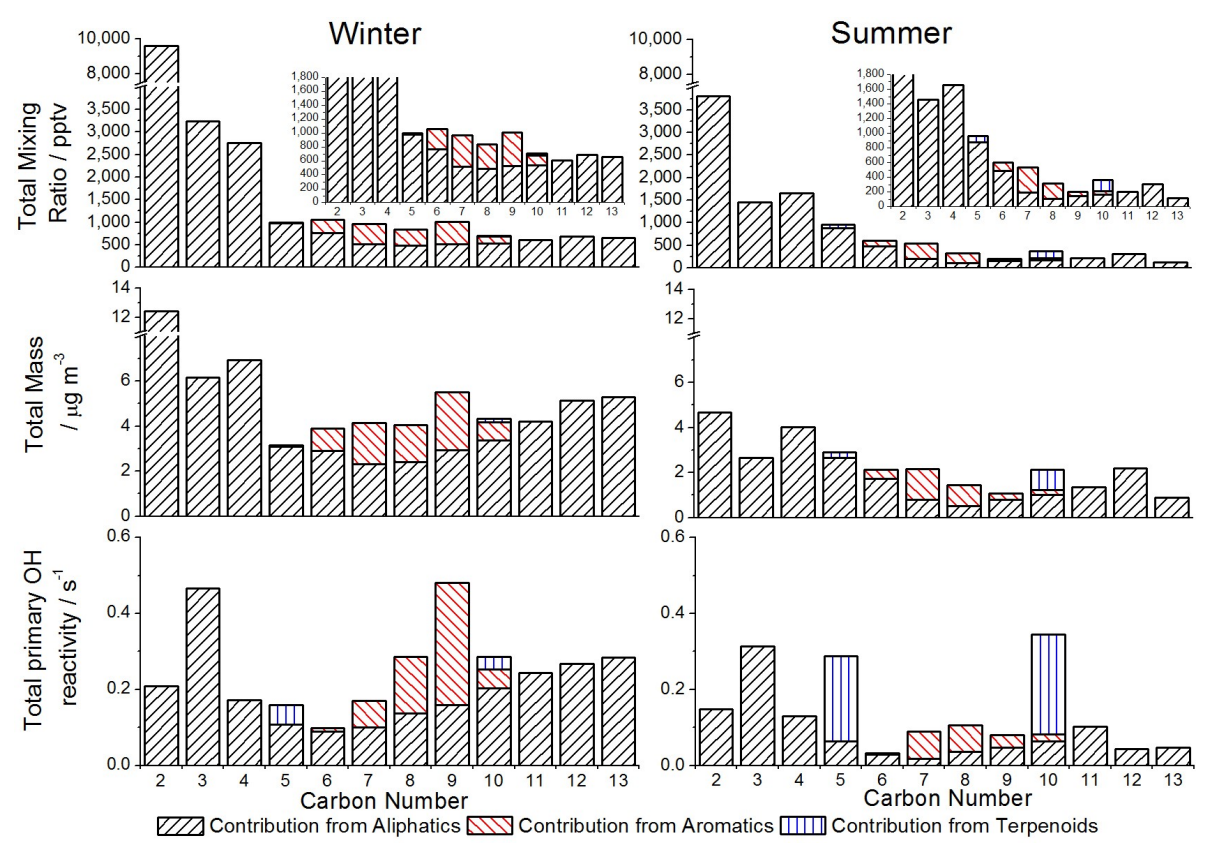

Figure 8. Seasonal median values for hydrocarbon mixing ratio, mass concentration and primary $\mathrm{OH}$ reactivity in London air grouped by carbon number and functionality 
Table 1. Comparison of London, North Kensington, LA and Bakersfield

\begin{tabular}{|c|c|c|c|c|c|c|c|c|c|c|}
\hline & \multirow{2}{*}{$\begin{array}{l}\text { Area } \\
\left(\mathbf{k m}^{2}\right)\end{array}$} & \multirow{2}{*}{$\begin{array}{l}\text { Number of } \\
\text { Inhabitants }\end{array}$} & \multirow{2}{*}{$\begin{array}{l}\text { Pop. density } \\
\left(\text { inhab. } \mathbf{k m}^{-2} \text { ) }\right.\end{array}$} & \multirow{2}{*}{$\begin{array}{c}\text { Cars per } \\
\text { household }\end{array}$} & \multirow{2}{*}{$\begin{array}{c}\text { Percent public } \\
\text { green space }\end{array}$} & \multirow{2}{*}{$\begin{array}{l}\text { Percent } \\
\text { diesel use }\end{array}$} & \multicolumn{2}{|c|}{ Average Temp. $\left({ }^{\circ} \mathrm{C}\right)$} & \multicolumn{2}{|c|}{ Average hrs sunlight } \\
\hline & & & & & & & Winter & Summer & Winter & Summer \\
\hline London & $1572^{a}$ & $7,825,200^{a}$ & $4978^{a}$ & $0.8^{f}$ & $38.4^{a}$ & $57^{9}$ & $3^{2}$ & $18.9^{2}$ & $2.2 k$ & $5.9^{k}$ \\
\hline NK & $12.13^{b}$ & $158,700^{c, d}$ & $13,087^{c, d}$ & $0.6^{f}$ & & $56^{c, g}$ & & & & \\
\hline LA & $10510^{a}$ & $9,818,605^{a}$ & $934^{a}$ & $1.9^{3}$ & $6.7 a$ & $13^{h}$ & $13.8^{j}$ & $21.4^{j}$ & $6.6^{l}$ & $11.1^{l}$ \\
\hline Bakersfield & $244.77^{b}$ & $357,603^{3}$ & $1461^{d}$ & & & $33^{h}$ & & & & \\
\hline $\begin{array}{l}\text { References } \\
{ }^{a} \text { World Citic } \\
{ }^{e} \text { US Census } \\
{ }^{i} \text { metoffice.g } \\
{ }^{l} \text { o }\end{array}$ & reau. ${ }^{f} \mathrm{U}$ & Office of Nat & nal Statistics. ${ }^{g}$ & $\begin{array}{l}\text { partment of } \\
\text { matemps.co }\end{array}$ & $\begin{array}{l}\text { nergy and Clim } \\
\text { temperatures.ph }\end{array}$ & $\begin{array}{l}\text { Change Sta } \\
\text { metoffice.g }\end{array}$ & mean & $\begin{array}{l}\text { gton and } \mathrm{Cl} \\
\text { et al. } 2012 \\
\text { hours of } \mathrm{st}\end{array}$ & ${ }^{d} \mathrm{C}$ & 12. \\
\hline
\end{tabular}

Table 2. Individually identified VOC mixing ratios, grouped by functionality, ordered by C number.

\begin{tabular}{|c|c|c|c|c|c|c|c|c|c|}
\hline \multirow[b]{2}{*}{ Compound } & \multicolumn{3}{|c|}{ Winter $^{a}$} & \multicolumn{3}{|c|}{ Summer $^{b}$} & \multirow[b]{2}{*}{$\begin{array}{l}\mathbf{L O D}^{c} \\
/ \text { pptv }\end{array}$} & \multirow[b]{2}{*}{$\begin{array}{l}\text { Measured } \\
\text { Using }\end{array}$} & \multirow[b]{2}{*}{$\begin{array}{c}\text { Peak } \\
\text { Identity }\end{array}$} \\
\hline & $\begin{array}{l}\text { Mean } \\
\text { / pptv }\end{array}$ & $\begin{array}{c}\text { Median } \\
\text { / pptv }\end{array}$ & $\begin{array}{c}\text { SD } \\
\text { /pptv }\end{array}$ & $\begin{array}{l}\text { Mean } \\
\text { / pptv }\end{array}$ & $\begin{array}{c}\text { Median } \\
\text { / pptv }\end{array}$ & $\begin{array}{c}\text { SD } \\
\text { /pptv }\end{array}$ & & & \\
\hline \multicolumn{10}{|l|}{ Saturated } \\
\hline Methane & $2.24 \times 10^{6}$ & $2.18 \times 10^{6}$ & $3.45 \times 10^{5}$ & $1.83 \times 10^{6}$ & $1.81 \times 10^{6}$ & $1.44 \times 10^{5}$ & 100 & DC-GC & - \\
\hline Ethane & 11,074 & 7,324 & 13,503 & 4,287 & 3,007 & 5,201 & 9 & DC-GC & - \\
\hline Propane & 4,250 & 2,944 & 4,207 & 1,703 & 1,253 & 1,514 & 3 & DC-GC & - \\
\hline$n$-Butane & 2,317 & 1,617 & 2,513 & 1,366 & 972 & 1,166 & 1 & DC-GC & - \\
\hline iso-Butane & 1,359 & 916 & 1,424 & 686 & 473 & 624 & 1 & DC-GC & - \\
\hline$n$-Pentane & 394 & 292 & 342 & 340 & 236 & 289 & 1 & DC-GC & - \\
\hline iso-Pentane & 833 & 574 & 825 & 751 & 540 & 647 & 1 & DC-GC & - \\
\hline Cyclopentane & 106 & 55 & 208 & 106 & 59 & 312 & 1 & DC-GC & - \\
\hline$n$-Hexane & 122 & 85 & 112 & 91 & 60 & 82 & 1 & DC-GC & 7 \\
\hline Pentane, 2+3-methyl- & 337 & 249 & 351 & 256 & 189 & 218 & 1 & DC-GC & 1 \\
\hline$n$-Heptane & 89 & 62 & 99 & 66 & 49 & 57 & 1 & DC-GC & 16 \\
\hline Butane, 2,2,3-trimethyl- & 111 & 78 & 107 & 71 & 55 & 50 & 1 & $\mathrm{GC} \times \mathrm{GC}$ & 12 \\
\hline$n$-Octane & 32 & 22 & 101 & 21 & 16 & 18 & 2 & DC-GC & 24 \\
\hline Pentane, 2,2,4-trimethyl- & 42 & 34 & 30 & 23 & 17 & 19 & 2 & DC-GC & 19 \\
\hline$n$-Nonane & 526 & 380 & 481 & 128 & 102 & 99 & 3 & $\mathrm{GC} \times \mathrm{GC}$ & 28 \\
\hline$n$-Decane & 398 & 328 & 339 & 132 & 87 & 138 & 2 & $\mathrm{GC} \times \mathrm{GC}$ & 41 \\
\hline Nonane, 2-methyl- & 50 & 35 & 49 & 43 & 28 & 44 & 4 & $\mathrm{GC} \times \mathrm{GC}$ & 34 \\
\hline$n$-Undecane & 397 & 288 & 364 & 165 & 125 & 123 & 1 & $\mathrm{GC} \times \mathrm{GC}$ & 50 \\
\hline$n$-Dodecane & 374 & 321 & 279 & 273 & 207 & 244 & 1 & $\mathrm{GC} \times \mathrm{GC}$ & 51 \\
\hline \multicolumn{10}{|l|}{ Unsaturated } \\
\hline Ethene & 1,703 & 1,340 & 1,477 & 638 & 508 & 402 & 7 & DC-GC & - \\
\hline Acetylene & 1,214 & 947 & 915 & 374 & 289 & 247 & 3 & DC-GC & - \\
\hline Propene & 425 & 275 & 465 & 199 & 163 & 124 & 3 & DC-GC & - \\
\hline Propadiene & 16 & 12 & 14 & 6 & 4 & 4 & 3 & DC-GC & - \\
\hline Propyne & & $\mathrm{N} / \mathrm{a}$ & & 44 & 37 & 16 & 3 & DC-GC & - \\
\hline Butene, trans-2- & 43 & 29 & 44 & 20 & 16 & 14 & 1 & DC-GC & - \\
\hline 1-Butene & 75 & 53 & 68 & 61 & 53 & 31 & 1 & DC-GC & - \\
\hline iso-Butene & 105 & 75 & 97 & 53 & 44 & 33 & 1 & DC-GC & - \\
\hline Butene, cis-2- & 28 & 19 & 30 & 14 & 11 & 11 & 1 & DC-GC & - \\
\hline 1,2-Butadiene & & N/a & & 143 & 67 & 885 & 1 & DC-GC & - \\
\hline 1,3-Butadiene & 53 & 39 & 47 & 32 & 26 & 19 & 1 & DC-GC & - \\
\hline Pentene, trans-2- & 48 & 29 & 152 & 26 & 21 & 24 & 1 & DC-GC & - \\
\hline 1-Pentene & 37 & 27 & 75 & 25 & 21 & 18 & 1 & DC-GC & - \\
\hline Isoprene & 28 & 19 & 31 & 117 & 88 & 111 & 1 & DC-GC & 2 \\
\hline Styrene & 34 & 17 & 54 & 33 & 19 & 34 & 8 & $\mathrm{GC} \times \mathrm{GC}$ & 30 \\
\hline$\alpha$-Pinene & 14 & 11 & 10 & 94 & 77 & 79 & 1 & $\mathrm{GC} \times \mathrm{GC}$ & 33 \\
\hline Limonene & 4 & 2 & 7 & 49 & 30 & 52 & 3 & $\mathrm{GC} \times \mathrm{GC}$ & 44 \\
\hline \multicolumn{10}{|l|}{ Aromatics } \\
\hline Benzene & 356 & 293 & 236 & 147 & 117 & 93 & 2 & DC-GC & 15 \\
\hline Toluene & 635 & 452 & 658 & 481 & 347 & 427 & 2 & DC-GC & 22 \\
\hline Benzene, ethyl- & 140 & 99 & 118 & 81 & 61 & 70 & 3 & DC-GC & 26 \\
\hline $\begin{array}{l}{ }^{a} \text { N/a indicates compounds } \\
{ }^{b} \text { Values in bold are higher } \\
{ }^{c}<\text { LOD indicates values } \\
{ }^{d} \text { Peak identity correspond }\end{array}$ & $\begin{array}{l}\text { that were no } \\
\text { during the su } \\
\text { at are below } \\
\text { to the labell }\end{array}$ & $\begin{array}{l}\text { measured d } \\
\text { mmer camps } \\
\text { the detectior } \\
\text { d peaks in } \mathrm{F}\end{array}$ & $\begin{array}{l}\text { uring the wir } \\
\text { ign } \\
\text { limit of the } \\
\text { igure } 5\end{array}$ & campaign & ent, calcula & $\mathrm{d}$ at $\mathrm{S} / \mathrm{N}=3$ & & & \\
\hline
\end{tabular}


Table 2. continued.

\begin{tabular}{|c|c|c|c|c|c|c|c|c|c|}
\hline \multirow[b]{2}{*}{ Compound } & \multicolumn{3}{|c|}{ Winter $^{a}$} & \multicolumn{3}{|c|}{ Summer $^{b}$} & \multirow[b]{2}{*}{$\begin{array}{l}\mathbf{L O D}^{c} \\
/ \text { pptv }\end{array}$} & \multirow[b]{2}{*}{$\begin{array}{c}\text { Measured } \\
\text { Using }\end{array}$} & \multirow[b]{2}{*}{$\begin{array}{c}\text { Peak } \\
\text { Identity }\end{array}$} \\
\hline & $\begin{array}{l}\text { Mean } \\
\text { / pptv }\end{array}$ & $\begin{array}{c}\text { Median } \\
\text { / pptv }\end{array}$ & $\begin{array}{c}\text { SD } \\
\text { /pptv }\end{array}$ & $\begin{array}{l}\text { Mean } \\
\text { / pptv }\end{array}$ & $\begin{array}{c}\text { Median } \\
\text { / pptv }\end{array}$ & $\begin{array}{c}\text { SD } \\
\text { /pptv }\end{array}$ & & & \\
\hline \multicolumn{10}{|l|}{ Aromatics continued } \\
\hline$m$ - and $p$-Xylene & 185 & 128 & 181 & 113 & 81 & 104 & 3 & DC-GC & 27 \\
\hline$o$-Xylene & 156 & 106 & 157 & 70 & 48 & 67 & 3 & DC-GC & 29 \\
\hline Benzene, iso-propyl- & 27 & 21 & 22 & & $<\mathrm{LOD}$ & & 3 & $\mathrm{GC} \times \mathrm{GC}$ & 32 \\
\hline Benzene, propyl- & 90 & 53 & 108 & 12 & 7 & 13 & 4 & $\mathrm{GC} \times \mathrm{GC}$ & 35 \\
\hline Toluene, 3-ethyl- & 139 & 84 & 160 & 17 & 8 & 26 & 6 & $\mathrm{GC} \times \mathrm{GC}$ & 36 \\
\hline Toluene, 4-ethyl- & 98 & 52 & 125 & 12 & 4 & 19 & 1 & $\mathrm{GC} \times \mathrm{GC}$ & 37 \\
\hline Benzene, 1,3,5-trimethyl- & 93 & 64 & 90 & 12 & 7 & 16 & 5 & $\mathrm{GC} \times \mathrm{GC}$ & 38 \\
\hline Toluene, 2-ethyl- & 65 & 41 & 71 & 8 & 3 & 12 & 6 & $\mathrm{GC} \times \mathrm{GC}$ & 39 \\
\hline Benzene, 1,2,4-trimethyl- & 195 & 120 & 224 & 27 & 15 & 42 & 1 & $\mathrm{GC} \times \mathrm{GC}$ & 42 \\
\hline Toluene, 4-iso-propyl- & 10 & 6 & 11 & 35 & 24 & 32 & 3 & $\mathrm{GC} \times \mathrm{GC}$ & 45 \\
\hline Benzene, 1,2,3-trimethyl- & 66 & 42 & 76 & 7 & 3 & 10 & 1 & $\mathrm{GC} \times \mathrm{GC}$ & 46 \\
\hline Indan & 11 & 8 & 9 & & $<$ LOD & & 4 & $\mathrm{GC} \times \mathrm{GC}$ & 47 \\
\hline Benzene, tert-butyl- & 7 & 4 & 7 & 10 & 3 & 14 & 1 & $\mathrm{GC} \times \mathrm{GC}$ & 43 \\
\hline Benzene, 1,3-diethyl- & 6 & 3 & 6 & 7 & 4 & 9 & 2 & $\mathrm{GC} \times \mathrm{GC}$ & 48 \\
\hline Benzene, 1,4-diethyl- & 5 & 3 & 7 & 3 & 2 & 3 & 1 & $\mathrm{GC} \times \mathrm{GC}$ & 49 \\
\hline Naphthalene & 36 & 25 & 35 & 35 & 26 & 29 & 3 & $\mathrm{GC} \times \mathrm{GC}$ & 52 \\
\hline \multicolumn{10}{|l|}{ Oxygenates } \\
\hline Acetaldehyde & 2,256 & 1,703 & 1,680 & 4,301 & 3,261 & 3,207 & 1 & DC-GC & - \\
\hline Propanal, 2-methyl- & & $<\mathrm{LOD}$ & & 48 & 32 & 43 & 6 & $\mathrm{GC} \times \mathrm{GC}$ & 5 \\
\hline Butanal & 9 & 5 & 15 & 13 & 8 & 13 & 1 & $\mathrm{GC} \times \mathrm{GC}$ & 11 \\
\hline Butanal, 3-methyl- & & $<\mathrm{LOD}$ & & 28 & 19 & 27 & 6 & $\mathrm{GC} \times \mathrm{GC}$ & 13 \\
\hline Butanal, 2-methyl- & & $<$ LOD & & 21 & 12 & 22 & 8 & $\mathrm{GC} \times \mathrm{GC}$ & 14 \\
\hline Methacrolein & & $<$ LOD & & 24 & 15 & 24 & 1 & $\mathrm{GC} \times \mathrm{GC}$ & 6 \\
\hline Pentanal & & $<\mathrm{LOD}$ & & 23 & 15 & 21 & 8 & $\mathrm{GC} \times \mathrm{GC}$ & 18 \\
\hline Hexanal & 9 & 6 & 10 & 19 & 11 & 19 & 3 & $\mathrm{GC} \times \mathrm{GC}$ & 25 \\
\hline Benzaldehyde & 24 & 16 & 25 & 13 & 9 & 12 & 1 & $\mathrm{GC} \times \mathrm{GC}$ & 40 \\
\hline Methanol & 1,246 & 962 & 1,605 & 3,376 & 2,462 & 2,580 & 40 & DC-GC & - \\
\hline Ethanol & 5,005 & 3,514 & 4,557 & 4,978 & 3,506 & 4,229 & 9 & DC-GC & - \\
\hline Propanol & 370 & 209 & 699 & 252 & 183 & 195 & 10 & DC-GC & - \\
\hline Butanol & 1,157 & 748 & 1,538 & 484 & 376 & 488 & 20 & DC-GC & - \\
\hline Acetone & 1,076 & 896 & 565 & 2,405 & 2,114 & 1,093 & 9 & DC-GC & 3 \\
\hline Butanone & 29 & 25 & 22 & 64 & 44 & 54 & 2 & $\mathrm{GC} \times \mathrm{GC}$ & 10 \\
\hline Ketone, methyl-vinyl- & & $<$ LOD & & 33 & 22 & 32 & 4 & $\mathrm{GC} \times \mathrm{GC}$ & 8 \\
\hline Pentanone, 2- & & $<$ LOD & & 29 & 19 & 28 & 1 & $\mathrm{GC} \times \mathrm{GC}$ & 17 \\
\hline Pentanone, 4-methyl-2- & 36 & 10 & 57 & 51 & 33 & 48 & 1 & $\mathrm{GC} \times \mathrm{GC}$ & 21 \\
\hline Hexanone, 2- & & $<\mathrm{LOD}$ & & 38 & 27 & 33 & 3 & $\mathrm{GC} \times \mathrm{GC}$ & 23 \\
\hline Cyclohexanone & & $<\mathrm{LOD}$ & & 17 & 11 & 18 & 9 & $\mathrm{GC} \times \mathrm{GC}$ & 31 \\
\hline Acetate, ethyl- & 45 & 34 & 40 & 46 & 30 & 44 & 2 & $\mathrm{GC} \times \mathrm{GC}$ & 9 \\
\hline \multicolumn{10}{|l|}{ Halogenated } \\
\hline Methane, dichloro & 29 & 18 & 31 & 35 & 25 & 29 & 2 & $\mathrm{GC} \times \mathrm{GC}$ & 4 \\
\hline Trichloroethylene & & $<$ LOD & & 10 & 7 & 8 & 5 & $\mathrm{GC} \times \mathrm{GC}$ & 20 \\
\hline $\begin{array}{l}{ }^{a} \text { N/a indicates compounds } \\
{ }^{b} \text { Values in bold are higher } \\
{ }^{c}<\text { LOD indicates values th } \\
{ }^{d} \text { Peak identity corresponds }\end{array}$ & $\begin{array}{l}\text { that were } \\
\text { during the } \\
\text { at are bel } \\
\text { to the lab }\end{array}$ & $\begin{array}{l}\text { not measu } \\
\text { summer c } \\
\text { elled peak }\end{array}$ & $\begin{array}{l}\text { ampaign } \\
\text { amption lim } \\
\text { in Figur }\end{array}$ & le winter & campaign & nent, c & culatec & $\mathrm{S} / \mathrm{N}=3$ & \\
\hline
\end{tabular}

Table 3. Grouped VOC mixing ratio and the number of isomers in each group.

\begin{tabular}{|c|c|c|c|c|c|c|c|}
\hline \multirow[b]{2}{*}{ Groups } & \multirow{2}{*}{$\begin{array}{l}\text { Number } \\
\text { of } \\
\text { Isomers }^{a}\end{array}$} & \multicolumn{3}{|c|}{ Winter $^{b}$} & \multicolumn{3}{|c|}{ Summer $^{b, c}$} \\
\hline & & $\begin{array}{l}\text { Mean } \\
\text { / pptv }\end{array}$ & $\begin{array}{c}\text { Median } \\
\text { /pptv }\end{array}$ & $\begin{array}{c}\text { SD } \\
\text { / pptv }\end{array}$ & $\begin{array}{l}\text { Mean } \\
\text { / pptv }\end{array}$ & $\begin{array}{c}\text { Median } \\
\text { /pptv }\end{array}$ & $\begin{array}{c}\text { SD } \\
/ \text { pptv }\end{array}$ \\
\hline $\mathrm{C}_{6}$ Aliphatics & 9 & 502 & 434 & 256 & 304 & 234 & 250 \\
\hline $\mathrm{C}_{7}$ Aliphatics & 10 & 586 & 379 & 617 & 127 & 93 & 132 \\
\hline $\mathrm{C}_{8}$ Aliphatics & 25 & 602 & 427 & 572 & 107 & 78 & 106 \\
\hline $\mathrm{C}_{9}$ Aliphatics & 28 & 214 & 143 & 220 & 79 & 49 & 98 \\
\hline $\mathrm{C}_{10}$ Aliphatics & 40 & 283 & 176 & 340 & 95 & 61 & 147 \\
\hline $\mathrm{C}_{11}$ Aliphatics & 41 & 459 & 320 & 452 & 137 & 89 & 209 \\
\hline $\mathrm{C}_{12}$ Aliphatics & 37 & 591 & 363 & 696 & 163 & 111 & 244 \\
\hline $\mathrm{C}_{13}$ Aliphatics & 30 & 937 & 654 & 914 & 187 & 117 & 170 \\
\hline $\mathrm{C}_{4}$ substituted monoaromatics & 16 & 210 & 102 & 298 & 33 & 14 & 57 \\
\hline $\mathrm{C}_{10}$ Monoterpenes & 25 & 13 & 7 & 17 & 51 & 34 & 48 \\
\hline \multicolumn{8}{|c|}{$\begin{array}{l}{ }^{a} \text { The number of isomers correspond to the groupings shown in the GC } \times \text { GC-FID plot shown in Figure } 2 \text { of the main paper } \\
{ }^{b} \text { Cumulative mixing ratio of each specified compound group not including those given individually in Table } 2 \\
\text { (i.e. the } \mathrm{C}_{7} \text { aliphatics are not including } n \text {-Heptane and } 2,2,3 \text {-trimethyl butane) } \\
{ }^{c} \text { Values in bold are higher during summer campaigns }\end{array}$} \\
\hline
\end{tabular}


Table 4. Room Temperature Rate Constants for the Gas-Phase Reactions of OH Radicals with $\mathrm{C}_{12}$ Aliphatic Compounds (Atkinson, 2003, Ziemann and Atkinson, 2012, Kwok and Atkinson, 1995, Atkinson and Arey, 2003; Aschmann and Atkinson 2008).

\begin{tabular}{|c|c|c|}
\hline \multirow[b]{2}{*}{ Structure } & \multicolumn{2}{|c|}{$\begin{array}{c}10^{12} \times k_{O H}{ }^{a} \\
\left(\mathbf{c m}^{3} \text { molecules }^{-1} \mathbf{s}^{-1}\right)\end{array}$} \\
\hline & Measured $^{b}$ & Calculated $^{c}$ \\
\hline \multicolumn{3}{|l|}{ Alkanes (linear, branched, cyclic) } \\
\hline$n$-dodecane & $13.2^{d}$ & 13.9 \\
\hline 2-methylundecane & - & 13.9 \\
\hline 2,2-dimethyldecane & - & 10.3 \\
\hline 3,3,4-trimethylnonane & - & 8.79 \\
\hline 6-ethyl-3-methylnonane & - & 14.9 \\
\hline 2,2,3,3,4,4-hexamethylhexane & - & 2.49 \\
\hline cyclododecane & - & 17.0 \\
\hline \multicolumn{3}{|l|}{ Alkenes/dienes } \\
\hline 1-dodecene & $50.3 \pm 1.3^{e}$ & 47.1 \\
\hline trans-5-dodecene & - & 71.1 \\
\hline 2,9-dimethyl-1,9-decadiene & - & 77.8 \\
\hline 2,4-dimethyl-2,4-decadiene & - & 176 \\
\hline \multicolumn{3}{|c|}{${ }^{a}$ All data measured/calculated at atmospheric pressure. } \\
\hline \multicolumn{3}{|c|}{ 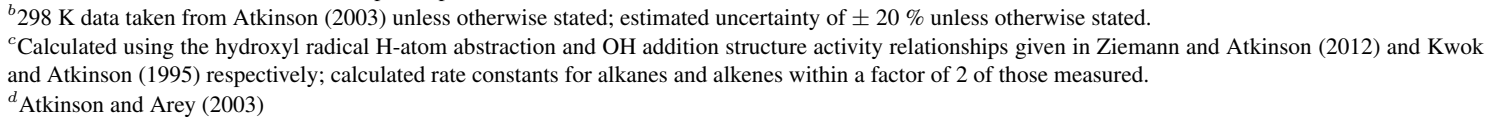 } \\
\hline
\end{tabular}

Table 5. Primary hydrocarbon $\mathrm{OH}$ reactivity $\left(\mathrm{s}^{-1}\right)$ divided by emission source for winter and summer

\begin{tabular}{lcccccc}
\hline & Natural Gas & Gasoline & $\begin{array}{l}\text { Total Diesel (Measured }+ \\
\text { Calculated }( \pm \text { error })\end{array}$ & Biogenic & OVOCs & Total $( \pm$ error $)$ \\
\hline Winter & 0.51 & 1.73 & $5.13(1.02+4.10( \pm 0.51))$ & 0.03 & 1.23 & $8.64( \pm 0.51)$ \\
Summer & 0.27 & 0.77 & $1.72(0.30+1.42( \pm 0.18))$ & 0.50 & 1.74 & $5.00( \pm 0.18)$ \\
\hline
\end{tabular}

Table 6. Contribution of total diesel to mixing ratio, mass, primary hydrocarbon $\mathrm{OH}$ reactivity and ozone formation potentials with and without $\mathrm{C}_{9}$ aromatic species

\begin{tabular}{lcccc}
\hline & \multicolumn{2}{c}{ Winter } & \multicolumn{2}{c}{ Summer } \\
\cline { 2 - 5 } & $\begin{array}{c}\text { With } \mathrm{C}_{9} \\
\text { aromatics }\end{array}$ & $\begin{array}{c}\text { Without } \mathrm{C}_{9} \\
\text { aromatics }\end{array}$ & $\begin{array}{c}\text { With } \mathrm{C}_{9} \\
\text { aromatics }\end{array}$ & $\begin{array}{c}\text { Without C } \\
\text { aromatics }\end{array}$ \\
\hline Mixing Ratio / \% & $34.5 \pm 3.5$ & $34.2 \pm 3.5$ & $21.2 \pm 2.2$ & $21.1 \pm 2.2$ \\
Mass / \% & $63.5 \pm 6.5$ & $63.0 \pm 6.5$ & $46.3 \pm 4.8$ & $46.2 \pm 4.8$ \\
OH reactivity / \% & $59.3 \pm 5.9$ & $58.3 \pm 5.9$ & $34.4 \pm 3.6$ & $34.2 \pm 3.6$ \\
Ozone formation potential / \% & $45.6 \pm 4.6$ & $43.5 \pm 4.6$ & $26.3 \pm 4.8$ & $25.9 \pm 4.8$ \\
\hline
\end{tabular}


Table 7. Fuel use changes for the UK

\begin{tabular}{|c|c|c|c|c|c|c|c|c|c|c|}
\hline \multirow[b]{2}{*}{ Year } & \multicolumn{4}{|c|}{ Personal Vehicles } & \multicolumn{3}{|c|}{ Freight } & \multirow[b]{2}{*}{$\begin{array}{c}\text { Total } \\
\text { Diesel }^{a}\end{array}$} & \multirow[b]{2}{*}{$\begin{array}{c}\text { Total } \\
\text { Petrol }^{b}\end{array}$} & \multirow{2}{*}{$\begin{array}{c}\% \\
\text { Diesel } \\
\text { Use }^{c}\end{array}$} \\
\hline & Buses & $\begin{array}{c}\text { Diesel } \\
\text { Cars }\end{array}$ & $\begin{array}{c}\text { Petrol } \\
\text { Cars }\end{array}$ & $\begin{array}{l}\text { Motor } \\
\text { Cycles }\end{array}$ & HGV & $\begin{array}{l}\text { Diesel } \\
\text { LGV }\end{array}$ & $\begin{array}{c}\text { Petrol } \\
\text { LGV }\end{array}$ & & & \\
\hline 2005 & $1,453.0$ & $5,836.0$ & $17,267.0$ & 198.0 & $7,577.0$ & $4,250.0$ & 377.0 & $19,116.0$ & $17,842.0$ & 52 \\
\hline 2006 & $1,476.0$ & $6,314.0$ & $16,687.0$ & 188.0 & $7,778.0$ & $4,424.0$ & 378.0 & $19,992.0$ & $17,253.0$ & 54 \\
\hline 2007 & $1,552.0$ & $6,731.0$ & $15,913.0$ & 200.0 & $7,956.0$ & $4,651.0$ & 345.0 & $20,890.0$ & $16,458.0$ & 56 \\
\hline 2008 & $1,505.0$ & $7,295.0$ & $14,830.0$ & 183.0 & $8,054.0$ & $4,652.0$ & 306.0 & $21,506.0$ & $15,319.0$ & 58 \\
\hline 2009 & $1,501.0$ & $7,370.0$ & $14,373.0$ & 187.0 & $7,413.0$ & $4,561.0$ & 277.0 & $20,845.0$ & $14,837.0$ & 58 \\
\hline 2010 & $1,495.0$ & $7,375.0$ & $13,477.0$ & 166.0 & $7,511.0$ & $4,606.0$ & 252.0 & $20,987.0$ & $13,895.0$ & 60 \\
\hline 2011 & $1,383.0$ & $7,663.0$ & $12,750.0$ & 167.0 & $7,311.0$ & $4,678.0$ & 234.0 & $21,035.0$ & $13,151.0$ & 62 \\
\hline
\end{tabular}

